\title{
Analisis Motor Brushless Direct Current Aksial Fluks 3 Fasa Menggunakan Magnet Permanen Neodymium Sebagai Prime Mover Generator
}

\author{
Mayang Karlia Sari ${ }^{1}$, Widyono Hadi $^{2}$, Widya Cahyadi ${ }^{3}$ \\ [Submission: 26-07-2020, Accepted: 11-12-2020]
}

\begin{abstract}
The increase in the use of conventional motor causes an increase in the use of petroleum that cannot be renewed. To overcome it the use of conventional motor changes to electric motor. Electric motor that are often used is brush motor, but it has brush-loss. Electric motor created to overcome the weakness of brush motor. Electric motor that are designed has specification ie 6 slot and use 4 dan 8 magnet in rotor. The coil in every slot is $\mathbf{4 5 0}$ made by email wire with $0,3 \mathrm{~mm}$ diameter.

This research is doing by measurement and calculation. Measurement is included measure magnetic field, motor voltage, frekuensi and rotational speed. Calculation is included power, torque, frekuensi and rotational speed. Motor testing is using 4 and 8 magnet in no load condition and with load condition. The first test on a 24 Volt supply voltage when using 4 magnets in no-load condition result a torque value of $1,09 \times 10^{-3} \mathrm{Nm}$ and a speed of 2794 RPM, when in load condition motor result torque value of $2,25 \times 10^{-3} \mathrm{Nm}$ and rotational speed of 1171 RPM. The second test on a 24 volt supply voltage when using 8 magnet in no-load condition motor result torque value of $3,38 \times 10^{-3} \mathrm{Nm}$ and rotational speed of 1410 RPM, when in load condition motor result torque of $7,4 \times 10^{-3} \mathrm{Nm}$ and rotational speed $1410 \mathrm{RPM}$. Maximal value torque result in all test is $7,4 \times 10^{-3} \mathrm{Nm}$ and maximal rotational speed is 2794 RPM.
\end{abstract}

Intisari-Peningkatan penggunaan motor konvensional menyebabkan peningkatan minyak bumi yang merupakan sumber daya alam yang tidak bisa diperbarui. Untuk mengatasi hal tersebut maka penggunaan motor konvensional diganti dengan motor listrik. Motor listrik yang sering digunakan adalah motor brush namun masih memiliki kekurangan yaitu terdapat rugi - rugi sikat. Sehingga dibuatlah motor brushless direct current untuk mengatasi hal tersebut. Motor yang dirancang pada penelitian ini memiliki spesifikasi 6 kumparan dengan jumlah magnet pada rotor 4 dan 8 . Lilitan pada masing - masing kumparan adalah 450 lilitan dengan kawat email berdiameter $0,3 \mathrm{~mm}$.

\footnotetext{
${ }^{1}$ Mahasiswa, Universitas Jember, Jl.Kalimantan no 37, Kampus Tegalboto, Jember, Telp:081336189545;e-mail: mayangkarlias@gmail.com

${ }^{2,3}$ Dosen, Jurusan Teknik Elektro Fakultas Teknik Universitas Jember, Jln.Kalimantan no 37 Jember 68121 INDONESIA (telp: 0361-703315); fax: 0361-4321;

email:widyono.hadi1961@gmail.com,cahyadi@unej.ac.id
}

Mayang Karlia Sari: Analisis Motor Brushless Direct...
Penelitian dilakukan dengan cara pengukuran dan perhitungan. Pengukuran meliputi pengukuran medan magnet, nilai tegangan motor, frekuensi dan kecepatan putar. Nilai perhitungan meliputi daya, torsi, frekuensi dan kecepatan putar motor. Pengujian dilakukan menggunakan 4 (empat) dan 8 (delapan) magnet bergantian serta dalam dua kondisi yaitu berbeban dan tanpa beban. Pengujian pertama pada tegangan sumber 24 Volt saat menggunakan 4 magnet dalam kondisi tanpa beban menghasilkan nilai torsi $1,09 x 10^{-3} \mathrm{Nm}$ dan kecepatan putar 2794 RPM, saat keadaan berbeban menghasilkan nilai torsi $2,25 x 10^{-3}$ dan nilai kecepatan putar 1171 RPM. Pengujian kedua tengan tegangan sumber 24 Volt menggunakan 8 magnet dihasilkan nilai torsi $3,38 \times 10^{-3} \mathrm{Nm}$ dan kecepatan putar 2484 RPM, saat keadaan berbeban dihasilkan nilai torsi $7,4 x 10^{-3} \mathrm{Nm}$ dan kecepatan putar motor 1410 RPM. Nilai torsi tertinggi yang dihasilkan yaitu $7,4 x 10^{-3} \mathrm{Nm}$ dan nilai kecepatan putar tertinggi yang dihasilkan yaitu 2794 RPM.

Kata Kunci-motor brushless direct current, torsi, kecepatan putar, magnet Neodymium

\section{PENDAHULUAN}

Peningkatan kebutuhan teknologi di berbagai bidang seperti bidang informasi dan alat transportasi menjadikan penggunaan motor juga semakin dibutuhkan. Peningkatan penggunaan motor linier dengan penggunaan sumber daya alam minyak bumi yang digunakan sebagai sumber energi motor konvensional. Penggunaan minyak bumi pada tahun 2017 sebesar 56,9\% dan tahun 2018 meningkat menjadi 58\% [1]. Karena ketersediaan sumber daya alam tersebut tidak bisa diperbaharui maka dibuat motor listrik sebagai pengganti motor konvensional. Selain itu motor listrik juga hampir bebas perawatan, tidak membutuhkan minyak, busi baru, atau perbaikan rutin lainnya seperti pada motor bakar [2].

Salah satu jenis motor listrik yang sering digunakan adalah motor DC, karena memiliki kelebihan yaitu kecepatannya mudah dikendalikan namun memiliki keandalan rendah karena menggunakan sikat atau brush serta motor DC membutuhkan pemeliharaan secara berkala [3]. Selain itu juga motor DC juga memiliki efisiensi sebesar $75 \%$ - $80 \%$ [4]. Penggunaan motor brushless DC dapat mengatasi kelemahan tersebut karena menggunakan komutasi elektrik sehinga memiliki efisiensi tinggi dan waktu operasi yang lama [5]. Efisiensi yang tinggi disebabkan karena tidak adanya gesekan oleh brush [6]. Selain itu motor brushless DC memiliki fitur p-ISSN:1693 - 2951; e-ISSN: 2503-2372 
yang rapat, tidak menimbulkan percikan api dan noise komutator, serta mampu digunakan di berbagai aplikasi seperti pada PC (Personal Computer) dan peralatan rumah tangga [7].

Motor brushless DC (BLDC) merupakan salah satu jenis motor yang memiliki ciri khas terdapat magnet permanen pada rotor dan kumparan pada stator. Salah satu jenis magnet permanen yang digunakan yaitu magnet Neodymium, yang merupakan jenis magnet terkuat dibanding magnet lainnya. Kuat medan magnet ini bisa berbahaya apabila tidak digunakan secara tepat [8]. Dilihat dari aliran fluknya, terdapat dua jenis motor brushless DC yaitu radial flux brushless DC dan axial flux brushless DC [9]. Beberapa penelitian yang sudah pernah dilakukan membuktikan bahwa motor brushless DC berbentuk aksial fluks memiliki nilai torsi lebih tinggi dibandingkan dengan radial fluks [10]. Motor yang berbentuk aksial fluks juga memiliki efisiensi lebih besar dari radial fluks [11]. Selain itu, motor brushless DC yang berbetuk radial fluks memiliki rugi daya yang lebih tinggi dibandingkan motor brushless DC berbentuk aksial fluks [12]. Motor brushless DC radial fluks memiliki efisiensi yang semakin tinggi apabila kecepatan putar juga semakin tinggi, namun pada kecepatan maksimal efisiensi tersebut akan menurun [13]. Meskipun motor ini termasuk motor sinkron AC 3 fasa, motor ini tetap disebut dengan brushless DC karena pada penerapannya menggunakan sumber DC sebagai sumber energi utama yang kemudian dengan inverter 3 fasa diubah menjadi tegangan AC 3. Tujuan dari pemberian tegangan AC 3 fasa pada stator brushless DC yaitu untuk menciptakan medan magnet putar stator untuk menarik magnet rotor [14].

Penelitian ini dilakukan untuk mengetahui kinerja dari motor brushless direct current 3 fasa aksial fluks saat menggunakan rotor dengan 4 magnet dan 8 magnet serta dalam keadaan berbeban dan tanpa beban. Parameter ukuran kinerja motor pada penelitian ini yang utama yaitu nilai torsi dan kecepatan putar motor. Parameter yang lain meliputi nilai tegangan luaran, frekuensi dan daya mekanik.

\section{METODE PENELITIAN}

\section{A. Alat dan Bahan}

Alat yang digunakan pada penelitian ini antara lain multimeter merek Krisbow KW06000832, tachometer merek Extech, tesla meter merek MetroLab PT2026, power supply merek CODY 3005DT, Osiloskop merek Hantek DSO5102P, driver KIT motor merek OWO model JYQD-V7 3E1, obeng, tang kombinasi, tang potong, solder, generator aksial fluks double rotor dengan magnet permanen Neodymium DC 24 Volt. Bahan - bahan yang digunakan antara lain yaitu Magnet permanen Neodymium tipe koin, isolasi/selotip kertas, akrilik, baut, mur, bearing, kabel penghubung, timah.

\section{B. Desain Motor Brushless Direct Current}

Pada penelitian motor brushless direct current aksial fluks 3 fasa ini meliputi komponen utama dari motor listrik, yaitu stator dan rotor dengan desain sebagai berikut:

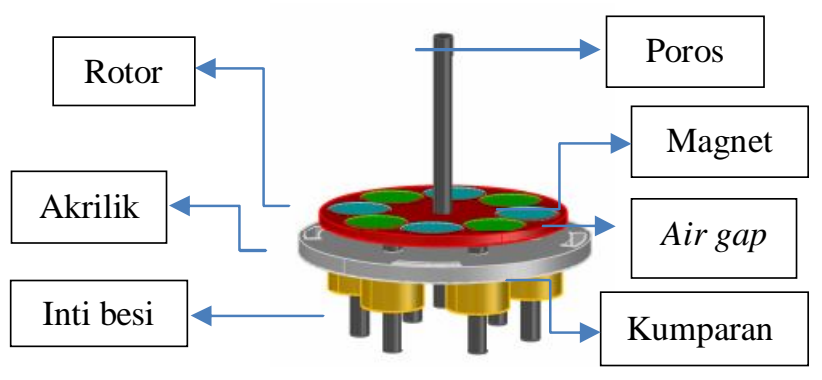

Gambar 1: Desain Motor Brushless Direct Current Aksial Fluks 3 Fasa

Jumlah lilitan sebanyak 450 lilitan dan total jumlah spul 6 buah sebagai kumparan. Perancangan menggunakan 4 dan 8 ini berdasarkan nilai minimum cogging torsi yang bisa didapatkan [15]. Kutub disusun melingkar dengan masing masing kutub terdapat inti besi, dipasang pada akrilik yang sekaligus berfungsi sebagai sekat antara rotor dan stator. Pada poros rotor dan stator dihubungkan menggunakan shaft sebagai transfer energi mekanik [16].Pada titik tengah stator terdapat bearing yang berguna sebagai bantalan agar poros busa berputar tanpa gesekan yang berlebih. Bearing yang digunakan memiliki ukuran diameter $1,5 \mathrm{~cm}$ dengan lebar lubang $0,5 \mathrm{~cm}$. Pada stator juga dipasang hall effect yang terletak di antara celah stator. Karena rangkaian stator menggunakan konfigurasi star maka dibutuhkan 3 sensor yang akan bekerja bergantian sebagai on dan off pada kumparan [17]. Pada penelitian sebelumnya, kemampuan sensor hall effect tetap efektif meskipun salah satu sensornya rusak atau tidak berfungsi [18].

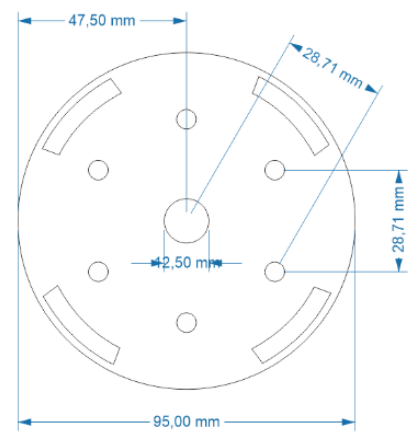

Gambar 2: Desain Stator Motor Brushless Direct Current Aksial Fluks 3 Fasa menggunakan 6 Kumparan

Perancangan rotor ada dua kondisi yaitu rotor dengan 4 magnet dan rotor dengan 8 magnet. Magnet yang digunakan berjenis Neodymium berbentuk koin berukuran 20x3 mm. Pemasangan magnet secara bersilang yaitu kutub utara (U) dan selatan $(\mathrm{S})$.

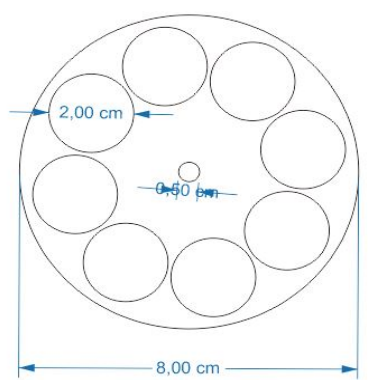

Gambar 3 : Desain Rotor Motor Brushless Direct Current Aksial Fluks 3 Fasa menggunakan 8 Magnet 


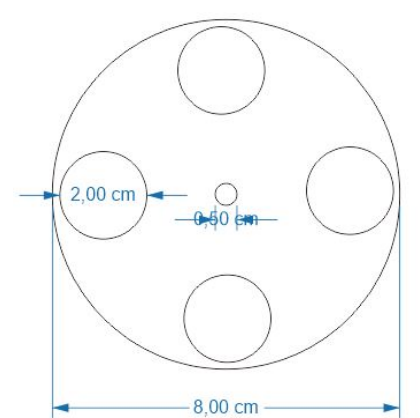

Gambar 4 : Desain Rotor Motor Brushless Direct Current Aksial Fluks 3 Fasa menggunakan 4 Magnet

C. Pengumpulan Data

1. Perhitungan

a. Nilai Medan Magnet

$B=B r \frac{i m}{i m+\Delta}$

Keterangan:

$\mathrm{B} \quad=$ Kuat medan magnet

$\mathrm{Br} \quad=$ Nilai medan magnet pengukuran $(\mathrm{T})$

im = Tebal magnet

$\Delta \quad=$ Lebar celah udara

b. Gaya pada Motor [17]

$$
F=k \frac{M 1 . M 2}{r^{2}}
$$

Keterangan:

$$
\begin{array}{ll}
F & =\text { Gaya } \\
M 1 & =\text { Total kuat medan magnet pada rotor } \\
M 2 & =\text { Total kuat medan magnet pada stator } \\
k & =\text { Konstanta } \\
\mathrm{r} & =\text { jarak antara rotor dan stator }
\end{array}
$$

dapat dijabarkan menjadi:

$M 1=A x H 1$, dimana H1yaitu:

$H 1=B \times 1$ Tesla

Keterangan:

$$
\begin{array}{lll}
A & =\text { Total luas permukaan magnet } & \left(\mathrm{m}^{2}\right) \\
B & =\text { Nilai medan magnet } & (\mathrm{T}) \\
\mathrm{H} 1 & =\text { Kuat medan magnet pada rotor } & (\mathrm{A} / \mathrm{m}) \\
\mathrm{H} 2 & =\text { Kuat medan magnet pada stator } & (\mathrm{A} / \mathrm{m}) \\
1 \text { Tesla } & =795774,715482221 &
\end{array}
$$

Penjabaran dari nilai M2 yaitu:

$M 2=A \times H 2$, dimana nilai $\mathrm{H} 2$ yaitu:

$H 2=\frac{2 x N x I a}{l}$

Keterangan:

$A \quad=$ Total luas permukaan magnet $\quad\left(\mathrm{m}^{2}\right)$

$N \quad=$ Jumlah lilitan stator

Ia $=$ Arus motor

$l \quad=$ panjang penampang kumparan c. Torsi Motor [19]

$$
T=F r
$$

Keterangan:

$$
\begin{array}{lll}
T & =\text { Torsi } & (\mathrm{Nm}) \\
F & =\text { Gaya } & (\mathrm{N}) \\
r & =\text { jari }- \text { jari rotor } & (\mathrm{m})
\end{array}
$$

d. Daya Mekanik [19]

$$
P=\omega T
$$

Keterangan:

$$
\begin{array}{lll}
P & =\text { Daya } & (\mathrm{W}) \\
T & =\text { Torsi } & (\mathrm{Nm}) \\
\omega & =\text { Kecepatan sudut } & (\mathrm{rad} / \mathrm{s})
\end{array}
$$

e. Kecepatan Sudut [19]

$$
\omega=\frac{2 \pi n_{r}}{60}
$$

Keterangan:

$\omega \quad=$ kecepatan sudut $\quad(\mathrm{rad} / \mathrm{s})$

$n_{r} \quad=$ kecepatan putaran motor $\quad(\mathrm{rpm})$

f. Kecepatan Putar Motor

Kecepatan putar motor dapat dihitung dari pengukuran frekuensi luaran driver dan jumlah kutub [20]

$n_{r}=\frac{120 f}{p}$

(2) Keterangan :

$$
\begin{array}{lll}
n_{r} & =\text { kecepatan putaran motor } & (\mathrm{rpm}) \\
f & =\text { frekuensi } & (\mathrm{Hz}) \\
p & =\text { jumlah pole } &
\end{array}
$$

g. Nilai Error [15]

$$
E \%=\left|\frac{H T-H p}{H T}\right| \times 100 \%
$$

Keterangan:

$\mathrm{Ht}=$ hasil perhitungan nilai frekuensi $(\mathrm{Hz})$ dan kecepatan putar motor (RPM)

$\mathrm{HP}=$ hasil perhitungan nilai frekuensi $(\mathrm{Hz})$ dan kecepatan putar motor (RPM)

\section{Pengukuran}

a. Pengukuran kuat medan magnet

Pengukuran medan magnet Neodymium yang digunakan pada penelitian, menggunakan alat Tesla meter, dengan cara sensor pada Teslameter diletakkan di atas magnet setelah itu akan didapatkan nilai medan magnet pada magnet Neodymium pada layar Teslameter.

b. Pemberian tegangan pada motor

Pada penelitian ini tegangan yang diberikan pada motor sebesar 12 volt sampai 24 volt. Tegangan didapatkan dari power supply yang dihubungkan ke kit driver motor.

c. Pengukuran kinerja motor

Pengukuran pada motor brushless direct current aksial fluks 3 fasa yaitu dengan mengukur pada setiap variasi tegangan menggunakan multimeter, kemudian setelah motor berputar akan diukur kecepatannya menggunakan tachometer, 
setelah itu arus dan tegangan pada motor diukur dengan multimeter, untuk arus diukur secara seri dan tegangan secara paralel. Setelah mendapatkan data tegangan, arus, dan kecepatan (RPM) maka dapat dihitung daya dan torsi.

\section{Tahapan Penelitian}

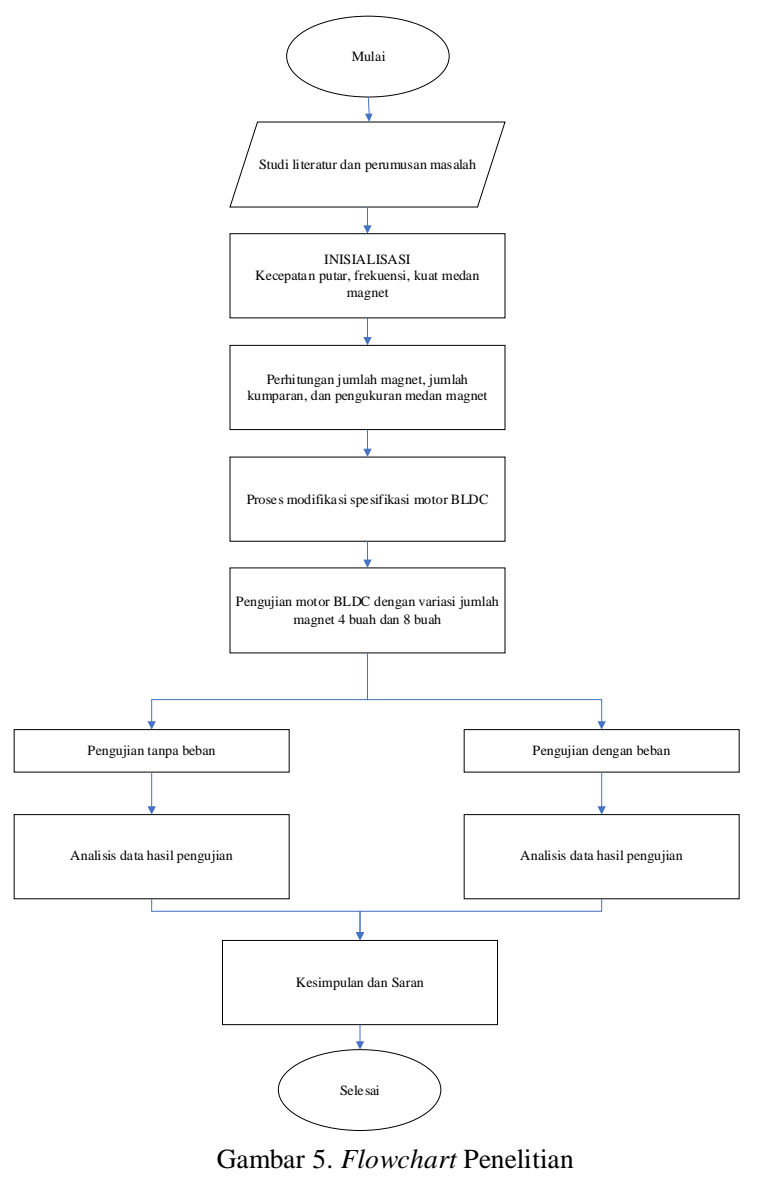

Tahapan yang dilakukan pada penelitian perancangan dan pembuatan motor BLDC aksial fluks:

1. Studi literatur

Pencarian literature dari hasil penelitian sebelumnya, buku maupun internet bertujuan untuk mengetahui karakteristik komponen, prinsip kerja serta teori yang menunjang lainnya guna diterapkan pada penelitian yang akan dilakukan. Setelah didapatkan literature yang sesuai selanjutnya adalah menentukan rumusan masalah dan juga dilakukan inisialisasi data - data yang akan digunakan pada penelitian, antara lain kecepatan putar, frekuensi, dan kuat medan magnet.

2. Melakukan perancangan motor BLDC meliputi menentukan jumlah magnet, jumlah kumparan dan melakukan pengukuran medan magnet. Luaran motor adalah 3 fasa, untuk menentukan jumlah magnet digunakan persamaan:

$N s=(p . N p h) / 2$

3. Melakukan modifikasi terhadap motor BLDC

Memodifikasi motor BLDC dari penelitian terdahulu menjadi memiliki diameter stator $95 \mathrm{~mm}$ dan rotor $80 \mathrm{~mm}$ serta memiliki 6 kumparan. Magnet menggunakan
Neodymium bentuk koin dengan ukuran $20 \times 3 \mathrm{~mm}$ sebanyak 4 (empat) magnet dan 8 (delapan) magnet.

4. Pengujian motor BLDC Aksial Fluks

Menguji performa motor tersebut dan mendapatkan data yang akan dipakai. Pengujian dilakukan dalam keadaan berbeban yaitu dikopel dengan generator dan ditambah resistor dan ketika tanpa beban, serta dalam dua kondisi yaitu menggunakan rotor dengan 4 magnet dan rotor dengan 8 magnet.

5. Penarikan kesimpulan

Pada tahapan akhir penelitian, hasil pengambilan data dan perhitungan dimasukkan ke pembahasan. Kemudian, dapat ditarik beberapa kesimpulan yang menyangkut kinerja dari alat yang telah dibuat.

\section{E. Blok Diagram}

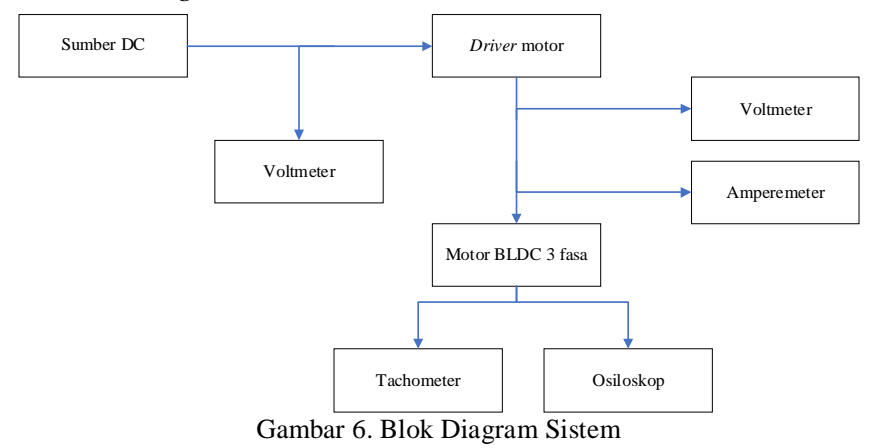

Prinsip kerja dari penelitian ini dapat digambarkan pada blok diagram seperti gambar 6 . Sumber yang digunakan adalah sumber DC yang berasal dari power supply. Pada motor brushless direct current aksial fluks 3 fasa, digunakan rotor yang terdapat magnet di tengahnya dan terdapat stator tunggal di bagian bawah. Di antara sumber DC dan driver motor diukur tegangan masukan, kemudian dari driver motor ke motor BLDC diukur tegangan luaran motor dan arus masukan. Pengukuran dari motor BLDC 3 fasa diberi tachometer untuk mengukur kecepatan putar dan osiloskop untuk mengukur frekuensi.

\section{HASIL DAN PEMBAHASAN}

TABEL 1

SPESIFIKASI MOTOR BRUSHLESS DIRECT CURRENT 3 FASA AKSIAL FLUKS

\begin{tabular}{ccc}
\hline Parameter & Simbol & Nilai \\
\hline Jumlah fasa & $N p h$ & $3 \mathrm{fasa}$ \\
Medan Magnet & $\mathrm{Br}$ & $0,089 \mathrm{~T}$ \\
Dimensi Magnet & $r$ & $1 \mathrm{~cm}$ \\
Ukuran Rotor & $l m$ & $0,3 \mathrm{cmm}$ \\
Jari - jari Rotor & $\mathrm{D}$ & $8 \mathrm{~cm}$ \\
Ukuran Stator & $\mathrm{D}$ & $4 \mathrm{~cm}$ \\
Jumlah Lilitan (tiap & $\mathrm{N}$ & $9,5 \mathrm{~cm}$ \\
kumparan) & $\mathrm{Ns}$ & 450 \\
Jumlah Kumparan & $\mathrm{Nm} \mathrm{1}$ & $6 \mathrm{buah}$ \\
Jumlah Magnet & $\mathrm{Nm} \mathrm{2}$ & $8 \mathrm{buah}$
\end{tabular}

Mayang Karlia Sari: Analisis Motor Brushless Direct... 
Majalah Ilmiah Teknologi Elektro, Vol. 19, No. 2, Juli-Desember 2020

DOI: https://doi.org/10.24843/MITE.2020.v19i02.P11

\begin{tabular}{ccc}
$\begin{array}{c}\text { Diameter Kawat } \\
\text { Email }\end{array}$ & $\mathrm{D}$ & $0,3 \mathrm{~mm}$ \\
Inti Besi & & Ya \\
Lebah Celah Udara & $\delta$ & $5 \mathrm{~mm}$ \\
Jarak antar magnet & $\tau f 1$ & $35,00 \mathrm{~mm}$ \\
& $\tau f 2$ & $26,79 \mathrm{~mm}$ \\
\hline
\end{tabular}

TABEL 2

SPESIFIKASI GENERATOR BRUSHLESS DIRECT CURRENT 3 FASA AKSIAL FLUKS DOUBLE STATOR

\begin{tabular}{ccc}
\hline Parameter & Simbol & Nilai \\
\hline Jumlah fasa & $\mathrm{Nph}$ & $3 \mathrm{fasa}$ \\
Medan magnet & $\mathrm{Br}$ & $0,089 \mathrm{~T}$ \\
Ukuran Magnet & $\mathrm{r}$ & $0,75 \mathrm{~cm}$ \\
Ukuran Rotor & $\mathrm{lm}$ & $2 \mathrm{~cm}$ \\
Ukuran stator & $\mathrm{D}$ & $7,2 \mathrm{~cm}$ \\
$\begin{array}{c}\text { Diamter kawat } \\
\text { Jarak antar } \\
\text { magnet }\end{array}$ & $\mathrm{D}$ & $8 \mathrm{~cm}$ \\
$\begin{array}{c}\text { Jumlah magnet } \\
\text { Jumlah lilitan } \\
\text { (tiap kumparan) }\end{array}$ & $\mathrm{Nm}$ & $0,5 \mathrm{~cm}$ \\
$\begin{array}{c}\text { Jumlah } \\
\text { kumparan }\end{array}$ & $\mathrm{N}$ & $2 \mathrm{~cm}$ \\
$\begin{array}{c}\text { Inti besi } \\
\text { Lebar celah } \\
\text { udara }\end{array}$ & $\mathrm{Ns}$ & $12 \mathrm{kumparan}$ \\
\hline
\end{tabular}

Tabel 1 menunjukkan spesifikasi motor brushless direct current yang digunakan pada penelitian dan tabel 2 menunjukkan spesifikasi generator yang digunakan pada penelitian sebagai beban.
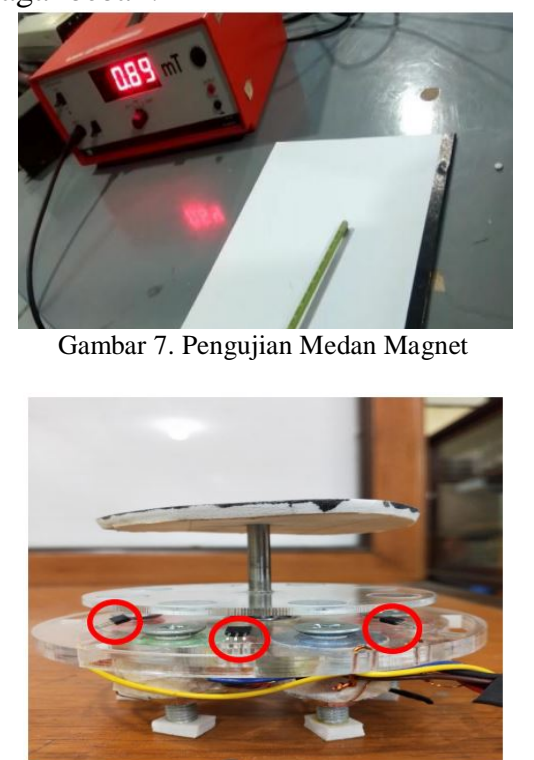

Gambar 8. Motor Brushless Direct Current 3 Fasa Aksial Fluks

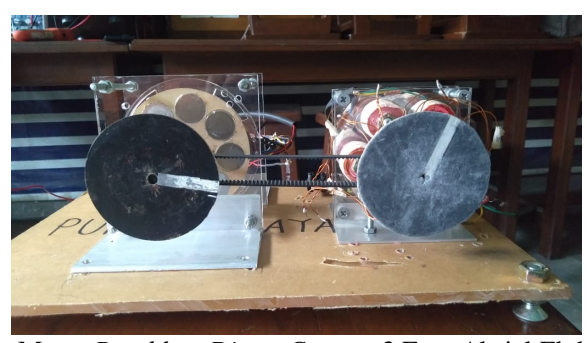

Gambar 9. Motor Brushless Direct Current 3 Fasa Aksial Fluks dikopel dengan Generator Tampak Depan

Gambar 7 menunjukkan hasil pengukuran medan magnet yaitu senilai 0,89 mT, gambar 8 menunjukkan motor brushless direct current 3 fasa aksial fluks tampak depan dan saat tidak berbeban. Pada gambar tersebut juga ditunjukkan penempatan 3 sensor hall effect di antara stator dan rotor. Gambar 9 menunjukkan motor brushless direct current 3 fasa aksial fluks saat dikopel dengan generator brushless direct current.

\section{A. Pengujian Motor Brushless Direct Current 3 Fasa Aksial Fluks tanpa Beban}

TABEL 3

HASIL PENGUJIAN MOTOR BRUSHLESS DIRECT CURRENT MENGGUNAKAN 4 MAGNET TANPA BEBAN

\begin{tabular}{|c|c|c|c|c|}
\hline $\begin{array}{c}\text { Tegangan } \\
\text { Sumber } \\
(\mathbf{V})\end{array}$ & $\begin{array}{c}\text { Arus } \\
\text { Motor } \\
(\mathbf{m A})\end{array}$ & $\begin{array}{c}\text { Tegangan } \\
\text { Line to } \\
\text { Line (V) }\end{array}$ & $\begin{array}{c}\text { Torsi } \\
(\mathbf{N m})\end{array}$ & $\begin{array}{c}\text { Daya } \\
(\mathbf{W})\end{array}$ \\
\hline 12 & 121 & 7,78 & $7,3 \times 10^{-4}$ & 0,098 \\
\hline 24 & 181 & 15,24 & $1,09 \times 10^{-3}$ & 0,319 \\
\hline
\end{tabular}

TABEL 4

GRAFIK FREKUENSI PENGUJIAN MOTOR BRUSHLESS DIRECT CURRENT MENGGUNAKAN 4 MAGNET TANPA BEBAN

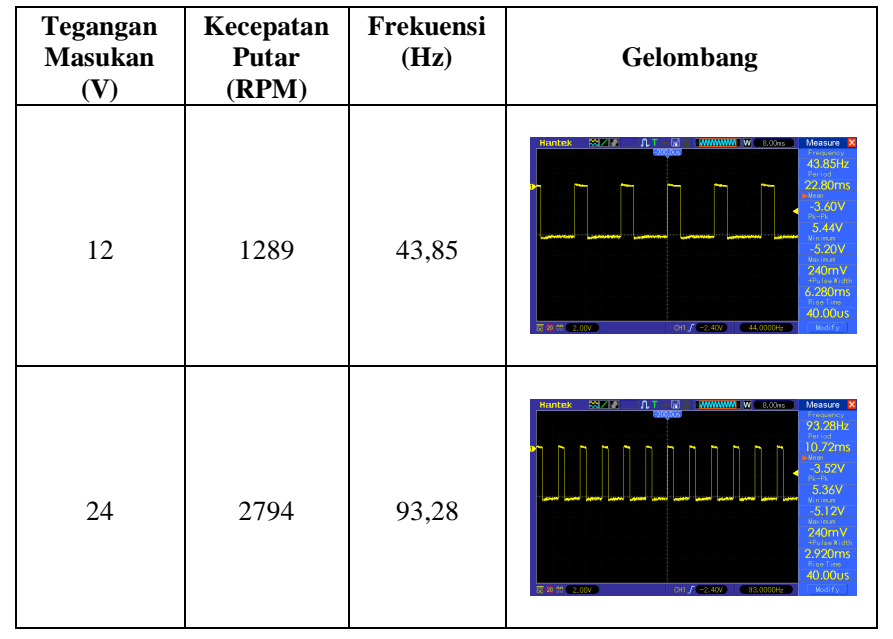

Hasil pengujian saat tidak berbeban menggunakan 4 magnet ditunjukkan tabel 3. Ketika tegangan masukan makin tinggi, maka nilai tegangan luaran makin tinggi diikuti peningkatan nilai kecepatan putar motor dan nilai torsi. Nilai kecepatan putar motor mempengaruhi nilai frekuensi, seperti ditunjukkan pada tabel 4. Makin tinggi nilai frekuensi motor maka sinyal akan makin rapat, sehingga sinyal pada tegangan

Mayang Karlia Sari: Analisis Motor Brushless Direct...

p-ISSN:1693 - 2951; e-ISSN: 2503-2372

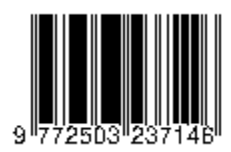


masukan 24 volt lebih rapat dibandingkan saat tegangan masukan 12 volt.

TABEL 5

HASIL PENGUJIAN MOTOR BRUSHLESS DIRECT CURRENT MENGGUNAKAN 8 MAGNET TANPA BEBAN

\begin{tabular}{|c|c|c|c|c|}
\hline $\begin{array}{c}\text { Tegangan } \\
\text { Sumber } \\
(\mathbf{V})\end{array}$ & $\begin{array}{c}\text { Arus } \\
\text { Motor } \\
(\mathbf{m A})\end{array}$ & $\begin{array}{c}\text { Tegangan } \\
\text { Line to } \\
\text { Line (V) }\end{array}$ & $\begin{array}{c}\text { Torsi } \\
(\mathbf{N m})\end{array}$ & $\begin{array}{c}\text { Daya } \\
(\mathbf{W})\end{array}$ \\
\hline 12 & 91,37 & 8,09 & $2,21 \times 10^{-3}$ & 0,276 \\
\hline 24 & 140,04 & 16,29 & $3,38 \times 10^{-3}$ & 0,879 \\
\hline
\end{tabular}

TABEL 6

GRAFIK FREKUENSI PENGUJIAN MOTOR BRUSHLESS DIRECT CURRENT MENGGUNAKAN 8 MAGNET TANPA BEBAN

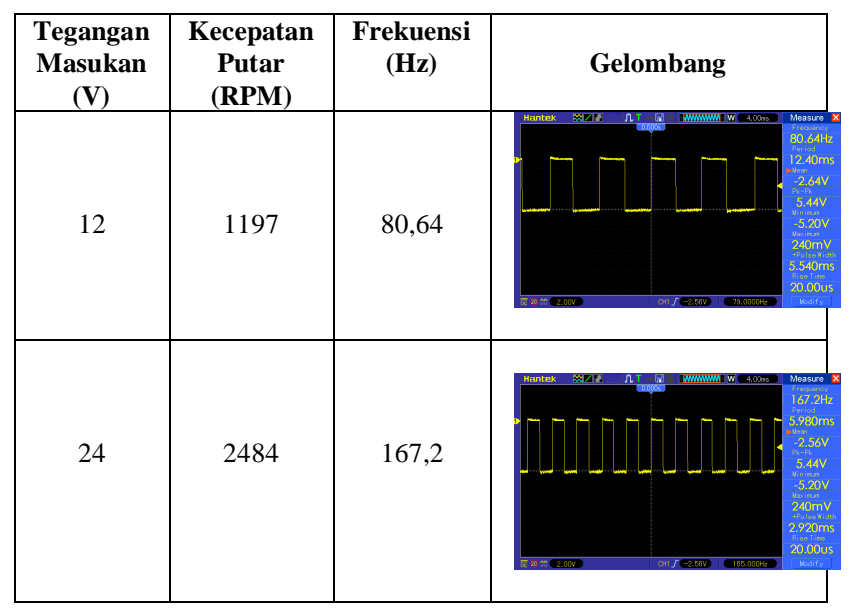

Hasil pengujian motor saat tidak berbeban dan menggunakan 8 magnet ditunjukkan pada tabel 5. Nilai - nilai parameter saat pengujian juga makin naik saat nilai tegangan masukan makin tinggi. Dibandingkan dengan pengujian menggunakan 4 magnet, pengujian menggunakan 8 magnet memiliki nilai torsi yang lebih tinggi namun memiliki nilai kecepatan putar yang lebih rendah. Perbedaan ini terlihat jelas jika ditunjukkan dalam bentuk grafik seperti gambar 10 dan gambar 11.

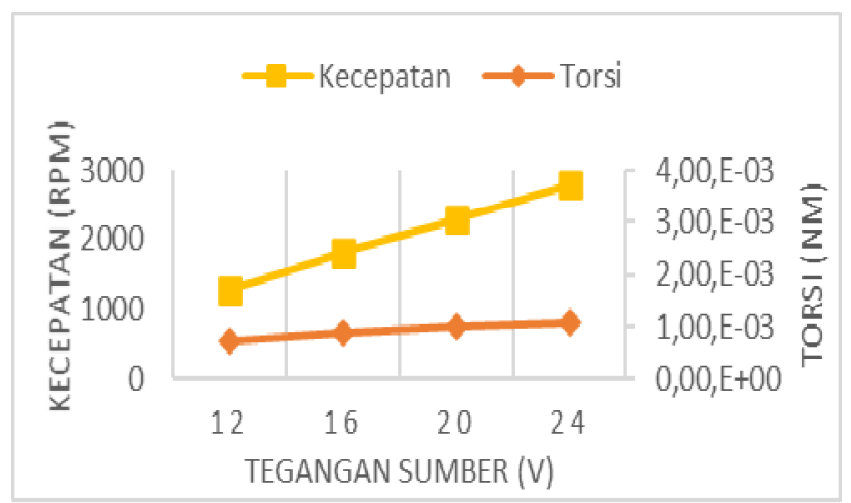

Gambar 10. Grafik Hubungan Kecepatan Putar Motor dengan Torsi pada Pengujian tanpa Beban menggunakan 4 Magnet

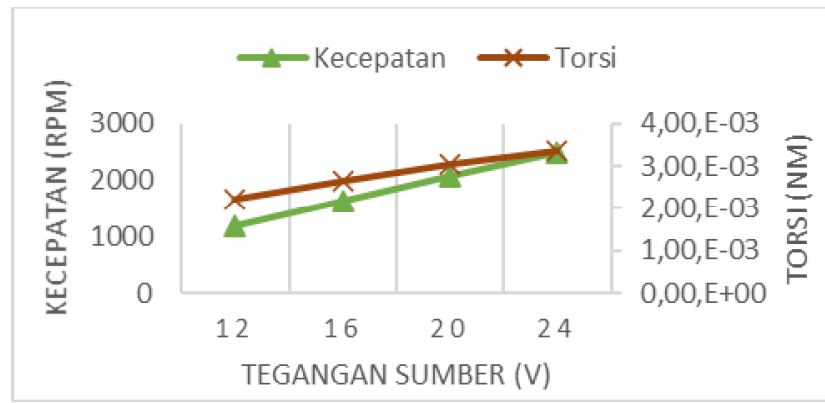

Gambar 11. Grafik Hubungan Kecepatan Putar Motor dengan Torsi pada Pengujian tanpa Beban menggunakan 8 Magnet

Grafik pada gambar 10 menunjukkan hubungan nilai torsi dan kecepatan putar motor saat pengujian dengan 4 magnet tanpa beban. Nilai kecepatan yang dihasilkan cukup tinggi yaitu maksimal 2794 RPM, merupakan nilai tertinggi dari semua pengujian dan nilai torsi maksimal yaitu $1,09 \times 10^{-3}$ $\mathrm{Nm}$. Gambar 11 menunjukkan grafik hubungan nilai torsi dan kecepatan putar motor saat menggunakan 8 magnet tanpa beban. Grafik menunjukkan nilai torsi yang lebih tinggi dibandingkan pada gambar 10. Maka saat pengujian dengan 8 magnet dihasilkan nilai torsi yang lebih tinggi namun nilai kecepatan lebih rendah jika dibandingkan dengan pengujian menggunakan 4 magnet. Karena nilai torsi dipengaruhi oleh jumlah magnet, sehingga makin banyak magnet yang digunakan akan menghasilkan nilai torsi yang makin tinggi.

\section{B. Pengujian Motor Brushless Direct Current 3 Fasa Aksial Fluks dikopel dengan Generator}

TABEL 7

HASIL PENGUJIAN MOTOR BRUSHLESS DIRECT CURRENT 3 FASA AKSIAL FLUKS MENGGUNAKAN 4 MAGNET NEODYMIUM DIKOPEL DENGAN GENERATOR

\begin{tabular}{|c|c|c|c|c|}
\hline $\begin{array}{c}\text { Tegangan } \\
\text { Sumber } \\
(\mathbf{V})\end{array}$ & $\begin{array}{c}\text { Arus } \\
\text { Motor } \\
(\mathbf{m A})\end{array}$ & $\begin{array}{c}\text { Tegangan } \\
\text { Line to } \\
\text { Line (V) }\end{array}$ & $\begin{array}{c}\text { Torsi } \\
\text { (Nm) }\end{array}$ & $\begin{array}{c}\text { Daya } \\
\text { (W) }\end{array}$ \\
\hline 12 & 213 & 7,07 & $1,29 \times 10^{-3}$ & 0,060 \\
\hline 24 & 373 & 15,09 & $2,25 \times 10^{-3}$ & 0,276 \\
\hline
\end{tabular}

TABEL 8

GRAFIK FREKUENSI PENGUJIAN MOTOR BRUSHLESS DIRECT CURRENT MENGGUNAKAN 4 MAGNET DIKOPEL DENGAN GENERATOR

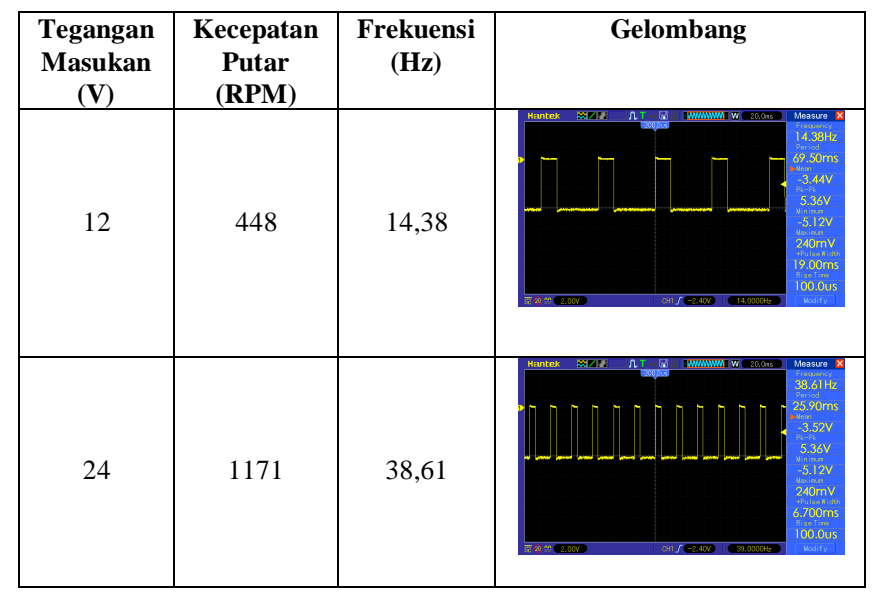


Pengujian selanjutnya yaitu motor dikopel dengan generator, dimana generator difungsikan sebagai beban. Pengujian pertama motor menggunakan 4 magnet dihasilkan data seperti pada tabel 7. Nilai torsi maksimal yang dihasilkan adalah $2,25 \times 10^{-3} \mathrm{Nm}$ dan kecepatan putar maksimal yang dihasilkan adalah 1171 RPM. Pada tabel 8 menunjukkan bahwa semakin besar nilai tegangan masukan, maka nilai frekuensi juga semakin besar dan sinyal semakin rapat.

TABEL 9

HASIL PENGUJIAN MOTOR BRUSHLESS DIRECT CURRENT 3 FASA AKSIAL FLUKS MENGGUNAKAN 8 MAGNET NEODYMIUM DIKOPEL DENGAN GENERATOR

\begin{tabular}{|c|c|c|c|c|}
\hline $\begin{array}{c}\text { Tegangan } \\
\text { Sumber } \\
\text { (V) }\end{array}$ & $\begin{array}{c}\text { Arus } \\
\text { Motor } \\
(\mathbf{m A})\end{array}$ & $\begin{array}{c}\text { Tegangan } \\
\text { Line to } \\
\text { Line (V) }\end{array}$ & $\begin{array}{c}\text { Torsi } \\
\text { (Nm) }\end{array}$ & $\begin{array}{c}\text { Daya } \\
\text { (W) }\end{array}$ \\
\hline 12 & 196 & 7,67 & $4,7 \times 10^{-3}$ & 0,288 \\
\hline 24 & 308 & 16,41 & $7,4 \times 10^{-3}$ & 1,097 \\
\hline
\end{tabular}

TABEL 10

GRAFIK FREKUENSI PENGUJIAN MOTOR BRUSHLESS DIRECT CURRENT MENGGUNAKAN 8 MAGNET DIKOPEL DENGAN GENERATOR

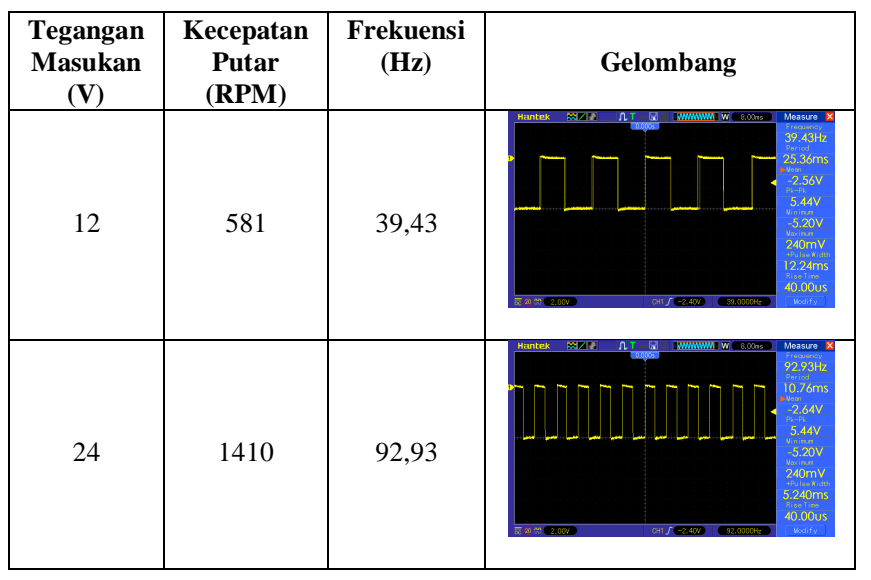

Pengujian selanjutnya adalah pengujian motor menggunakan 8 magnet dikopel dengan generator. Data hasil pengujian ditunjukkan pada tabel 9. Pada pengujian ini nilai data yang dihasilkan lebih tinggi dibandingkan saat pengujian menggunakan 4 magnet dengan beban. Perbandingan dengan grafik ditunjukkan pada gambar 12 dan gambar 13 .

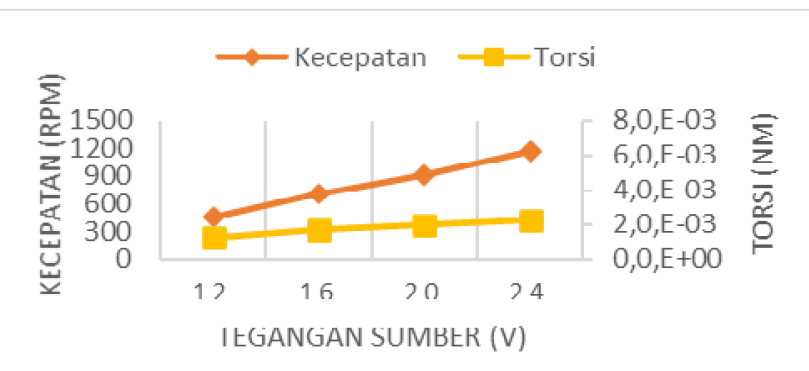

Gambar 12. Grafik Hubungan Kecepatan Putar Motor dengan Torsi pada Pengujian dengan Kopel Generator menggunakan 4 Magnet

Mayang Karlia Sari: Analisis Motor Brushless Direct...

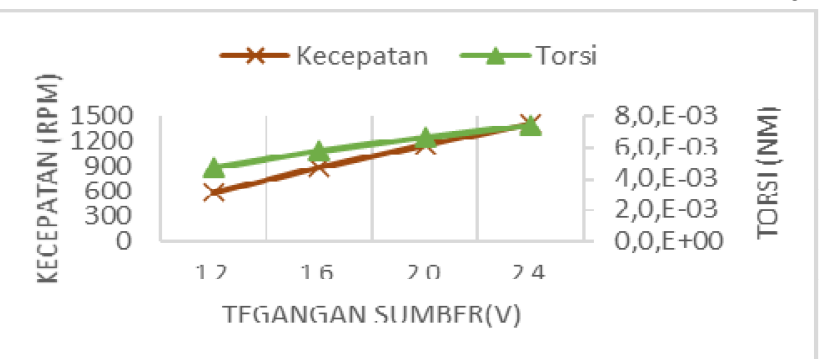

Gambar 13. Grafik Hubungan Kecepatan Putar Motor dengan Torsi pada Pengujian dengan Kopel Generator menggunakan 8 Magnet

Gambar 12 menunjukkan grafik hubungan torsi dan kecepatan putar saat pengujian motor menggunakan 4 magnet dikopel dengan generator. Jika dibandingkan dengan gambar 13 yaitu grafik hubungan torsi dan kecepatan putar saat pengujian motor menggunakan 8 magnet dikopel dengan generator, pengujian saat menggunakan 4 magnet menghasilkan nilai torsi dan kecepatan yang lebih rendah. Nilai torsi tertinggi pada semua pengujian dihasilkan saat pengujian menggunakan 8 magnet dikopel dengan generator, yaitu $7,4 \times 10^{-3} \mathrm{Nm}$.

\section{KESIMPULAN}

Kesimpulan dari hasil penelitian ini adalah:

1. Hasil pengujian dari motor dengan jumlah magnet yang berbeda, pada pengaplikasian motor sebagai prime mover generator ketika menggunakan 4 magnet hasilnya kurang maksimal karena menghasilkan nilai torsi yang kecil yaitu2,25 $\times 10^{-3} \mathrm{Nm}$, sedangkan ketika menggunakan 8 magnet motor sebagai prime mover generator bekerja secara maksimal dengan nilai torsi paling tinggi dari semua pengujian yaitu $7,4 \times 10^{-3} \mathrm{Nm}$.

2. Hasil pengujian prototype motor brushless direct current 3 fasa aksial fluks sebagai prime mover generator menggunakan magnet Neodymium dalam keadaan berbeban dan tanpa beban berhasil dilakukan dengan hasil ketika motor dalam keadaan tidak berbeban didapatkan nilai kecepatan putar tertinggi dari semua pengujian yaitu 2794 RPM saat pengujian menggunakan 4 magnet, sedangkan ketika pengujian berbeban nilai kecepatan putar motor maksimal adalah 1410 RPM. Sehingga nilai kecepatan putar tertinggi yaitu saat motor dslam keadaan tidak berbeban.

\section{REFERENSI}

[1]. Prabowo, Susetyo Edi et al. 2018. Handbook of Energy \& Economic Statistics. Indonesia: Ministry of Energy and Mineral Resources.

[2]. Naser Azizi, Reihaneh Kardehi Moghaddam. 2013. Permanent Magnet Brushless DC Motor Optimal Design and Determination of Optimum PID Controller Parameters for the Purpose of Speed Control by Using the TLBO Optimization Algorithm. American Journal of Research Communication.

[3]. Bagia, I Nyoman dkk. 2018. Motor - Motor Listrik. Kupang: CV Rasi Terbit.

[4]. Gifary, Heristo Bramasta. 2017. Rancang Bangun Motor BLDC Tiga Fasa Sensorless dengan Tipe Konstruksi Out-Runner. Jember: Universitas Jember.
p-ISSN:1693 - 2951; e-ISSN: 2503-2372 
[5]. Zainal, Nur Roin. 2018. Pengaruh Posisi Sudut Optimum Reed Switch pada Motor Brushless DC Axial Flux. Jember: Universitas Jember.

[6]. Bashir Sheikh, Priti. S. 2016. Manware Brushless DC Motor Design for Electric Traction System. Journal for Research.

[7]. Nidec. 2019. Brushless DC Motors Exhibit Reduced Energy Use, Long Life, Low Noise, Compact Size and Light Weight Characteristics diakses tanggal 9 Desember 2020, dari Nidec Corporation: https://www.nidec.com/en/technology/capability/brushless

[8]. Hill, A. (2019, Oktober $\left.29^{\text {th }}\right)$. What are Neodymium Magnets?. B. Haris, Editor) diakses tanggal 9 Desember 2020, dari Wisegeek: https://www.wisegeek.com/what-are-neodymiummagnets.htm

[9]. Janardana, Gede Bayu Anugrah. 2015. Desain dan Analisis Motor Axial Flux Brushless DC Berbasis 3D Finite Element Method untuk Aplikasi Kendaraan Listrik. Surabaya: Institut Teknologi Sepuluh Nopember.

[10]. Simsir, N. B., \& Erthan. H. B. 1999. A Comparison of Torque Capabilities of Axial Flux and Radial Flux Type of Brushless DC (BLDC) Drives for Wide Speed Range Applications. (1999 International Conference on Power Electronics and Drive Systems). Hongkong: IEEE.

[11]. Clemens, K. (2018, Mei $\left.23^{\text {rd }}\right)$. A New Generation of Axial Flux EV Motors. Diakses tanggal 9 Desember 2020, dari Magnax: https://www.magnax.com/blog/a-new-generation-of-axial-fluxevmotors
[12]. Aydin, M. 2008. Magnet Skew in Cogging Torque Minimization of Axial Gap Permanent Magnet Motors. (18th International Conference of Electrical Machines). Vilmoura: IEEE.

[13]. Alberti, L., \& Berardi, G. 2018. Design of a Low Power Synchronous Motor for High Efficiency Applications. XIII International Conference Electrical Machines (ICEM). Alexandropouli: IEEE.

[14]. Dharmawan, Abe. 2009. Pengendali Motor DC Brushless dengan Metode PWM Sinusoidal Menggunakan ATMega 16. Depok: Universitas Indonesia.

[15]. Reqzy, Muhammad. 2019. Rancang Bangun Motor Brushless Direct Current 3 Phase Fluks Axial. Jember: Universitas Jember.

[16]. Krstic, M. (2011, Desember 21 ${ }^{\text {st }}$ ). Axial Flux Motor. Diakses tanggal 9 Desember 2020 dari Flyingv: http://flyingv.ucsd.edu/nima/Axial_Flux/Axial_Flux.html

[17]. Nurtiantono, Agus. 2014. Rancang Bangun Dan Uji Performa Axial Brushless DC Motor Dengan Daya Output 2000 Watt. Surabaya: Institut Teknologi Sepuluh Nopember.

[18]. Nama, T., Gogoi, A.K., \& Tripathy, P. 2017. Application of a Smart Hall Effect Sensor System for 3-phase BLDC Drives. 2017 IEEE Symposium on Robotics and Intelligent Sensors (IRIS). Ottawa: IEEE.

[19]. Miller, Tje. 1994. Design of Brushless Permanent-Magnet Motor. Oxford: Oxford University Press.

[20]. Chapman, S. J. 2012. Electric Machinery Fundamentals, 5th Edition. Melbourne: McGraw-Hill. 